FLEXIBLE URBAN TRANSPORTATION 


\section{Related books}

CULLINANE \& STOKES

HENSHER (ed.)

HENSHER \& BUTTON (eds.)

MAHMASSANI

ROOT

TANIGUCHI

TANIGUCHI \& THOMPSON

TURRÓ
Rural Transport Policy

Travel Behaviour Research: The Leading Edge

Handbooks in Transport Series

In Perpetual Motion: Travel Behaviour Research Opportunities and Application Challenges

Delivering Sustainable Transport: A Social Science Perspective

City Logistics

Logistics Systems for Sustainable Cities

Going trans-European: Planning and Financing Transport Networks for Europe 


\title{
FLEXIBLE URBAN TRANSPORTATION
}

\author{
By \\ Jonathan L Gifford \\ George Mason University, Arlington, USA
}

Emerald

United Kingdom - North America - Japan

India - Malaysia - China 
Emerald Group Publishing Limited

Howard House, Wagon Lane, Bingley BD16 1WA, UK

First edition 2003

Copyright (C) 2003 Emerald Group Publishing Limited

\section{Reprints and permission service}

Contact: booksandseries@emeraldinsight.com

No part of this book may be reproduced, stored in a retrieval system, transmitted in any form or by any means electronic, mechanical, photocopying, recording or otherwise without either the prior written permission of the publisher or a licence permitting restricted copying issued in the UK by The Copyright Licensing Agency and in the USA by The Copyright Clearance Center. No responsibility is accepted for the accuracy of information contained in the text, illustrations or advertisements. The opinions expressed in these chapters are not necessarily those of the Editor or the publisher.

\section{British Library Cataloguing in Publication Data}

A catalogue record for this book is available from the British Library

ISB N : 978-0-08-050656-2

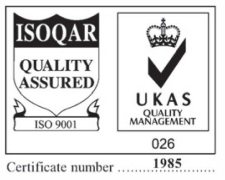

Awarded in recognition of Emerald's production department's adherence to quality systems and processes when preparing scholarly journals for print

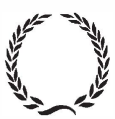

INVESTOR IN PEOPLE 


\section{Preface}

This book is a critique of transportation planning as it is practiced in the United States today and a proposal for a new, more flexible approach. The U.S. is now facing profound challenges to its economic competitiveness and social equity, to public safety and security, and to the integrity of its environment. The ability to create transportation systems that contribute to addressing those challenges effectively requires a planning process radically different from the process in place today. Meeting the nation's challenges effectively requires flexibility, honesty about what does and does not work, transparency, and inclusion of a broad range of stakeholders. The current process is rigid, dishonest - the process, that is, not the professionals who work in it - opaque, and exclusive.

This call for reform is in some ways both naïve and imperfect. The current transportation planning process is deeply ingrained in institutions and procedures that direct substantial funds to well-entrenched interests. It is unlikely that a new approach can displace the status quo any time soon, and any real change in practice that the proposed reform might engender will invariably raise questions that the book fails to address. Nonetheless, I offer it in the spirit of constructive criticism on a matter of great societal urgency.

The motivation for writing this book goes back two decades to my doctoral dissertation on the planning and design of the interstate highway system and its impacts on American cities. In that work I asked, how could a program as widely welcomed and well-intentioned as the Interstate program in 1956 have unleashed such a furious rejection in so many cities only a decade later? The answer lay in the nature of bureaucratic politics and the perils of implementation and unintended consequences.

This book takes the logical next step and examines the difficult and humbling question of what can and should be done to remedy the transportation planning crisis. The book describes how transportation planning has reached its troubled present state, and prescribes a way forward. Many of the ideas and proposals presented here are not wholly new. Indeed, the proposed approach builds on what is best about transportation planning today. It seeks to relax some of the procedural and societal constraints on discovering the proper balance between transportation improvements and other objectives of the society those improvements are intended to serve. Yet while promising signs of improvement are apparent here and there, much about the current practice of transportation planning reflects the best thinking of the 1950s, frozen in the amber of regulations, consent decrees, and procedural checkpoints. These frustrate attempts for reform, with the consequence that the transportation system fails to serve society as well as it could.

The book has been a labor of many years, and I owe a debt of gratitude to many. At George Mason University, Louise White helped inspire the writing. Jim Pfiffner offered valuable advice and counsel. Roger Stough and the School of Public Policy provided extremely generous encourage- 
ment and financial support. Graduate students Sanjay Marwah, Danilo Pelletiere, and Odd Stalebrink have provided indispensable research assistance. For several years, Mary Clark provided essential administrative support, as well as great working companionship. Many colleagues debated and discussed ideas presented in the book. And the university itself provided an intellectual setting in which I could develop and complete the manuscript.

Outside the university, I am indebted to my editor, Chris Pringle and his able and patient staff at Elsevier Science, to Richard Rowson, who provided invaluable editorial advice, to Catherine Kreyche, who copyedited the manuscript and supervised its preparation, and to Thanigai Tiruchengodu for his assistance with computer graphics. Last but not least, my good friend Bob Vastine provided warmly appreciated support, prodding, and encouragement over the long course of its development. To all, a sincere and heartfelt thank you.

Of course, the normal disclaimers apply. 